\title{
Article \\ Effect of Sea Buckthorn (Hippophae rhamnoides L.) Mousse on Properties of Probiotic Yoghurt
}

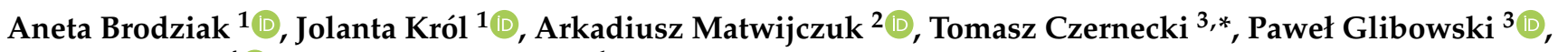 \\ Łukasz Wlazło $^{4}$ (D) and Anna Litwińczuk ${ }^{1}$
}

check for

updates

Citation: Brodziak, A.; Król, J.;

Matwijczuk, A.; Czernecki, T.;

Glibowski, P.; Wlazło, Ł.; Litwińczuk,

A. Effect of Sea Buckthorn (Hippophae rhamnoides L.) Mousse on Properties of Probiotic Yoghurt. Appl. Sci. 2021, 11, 545. https://doi.org/10.3390/ app11020545

Received: 2 December 2020

Accepted: 5 January 2021

Published: 8 January 2021

Publisher's Note: MDPI stays neutral with regard to jurisdictional clai$\mathrm{ms}$ in published maps and institutional affiliations.

Copyright: (C) 2021 by the authors. Licensee MDPI, Basel, Switzerland. This article is an open access article distributed under the terms and conditions of the Creative Commons Attribution (CC BY) license (https:// creativecommons.org/licenses/by/ $4.0 /)$.
1 Institute of Quality Assessment and Processing of Animal Products, Faculty of Animal Sciences and Bioeconomy, University of Life Sciences in Lublin, Akademicka 13, 20-950 Lublin, Poland; aneta.brodziak@up.lublin.pl (A.B.); jolanta.krol@up.lublin.pl (J.K.); anna.litwinczuk@up.lublin.pl (A.L.)

2 Department of Biophysics, University of Life Sciences in Lublin, Akademicka 13, 20-950 Lublin, Poland; arkadiusz.matwijczuk@up.lublin.pl

3 Department of Biotechnology, Microbiology and Human Nutrition, Faculty of Food Science and Biotechnology, University of Life Sciences in Lublin, Skromna 8, 20-704 Lublin, Poland; pawel.glibowski@up.lublin.pl

4 Department of Animal Hygiene and Environmental Hazards, Faculty of Animal Sciences and Bioeconomy, University of Life Sciences in Lublin, Akademicka 13, 20-950 Lublin, Poland; lukasz.wlazlo@up.lublin.pl

* Correspondence: tomasz.czernecki@up.lublin.pl

\begin{abstract}
The stability of the physico-chemical and sensory characteristics of yoghurts during refrigerated storage is important for industry and the consumer. The aim of the study was to evaluate the nutritional value, microbiological quality, sensory properties, and structure of natural probiotic yoghurts made with the addition of sea buckthorn fruit mousse during refrigerated storage. In this study, we produced natural, probiotic organic yoghurts with the addition of superfoods, i.e., sea buckthorn (Hippophae rhamnoides L.) fruit mousse, using ABT-1 probiotic yoghurt starter culture based on Lactobacillus acidophilus LA-5, Bifidobacterium lactis BB-12, and Streptococcus thermophilus. Physicochemical (acidity, nutritional value, and structure) as well as microbiological and sensory changes occurring during 21-day refrigerated storage were determined. The yoghurts were characterized by high sanitary and hygienic quality during the whole refrigerated storage. Fourier-Transform Infrared (FTIR) spectra were also used in the analyses of the obtained yoghurt samples. The applied yoghurt additive was visible at the spectral level as an increase in the intensity of the characteristic bands for vibrations related to protein, fat, and polysaccharide structures. Sea buckthorn can be used as a modern and unconventional addition to yoghurts with health-promoting properties. Micrographic studies have shown that the addition of sea buckthorn mousse significantly changes the microstructure of the yoghurt. The structure of sea buckthorn to yoghurt seems to be more susceptible to the influence of damaging factors, which is also confirmed by the FTIR test conducted during the storage.
\end{abstract}

Keywords: yoghurt; storage; nutritional value; sensory properties; microbiological quality; scanning electron microscopy; FTIR spectroscopy

\section{Introduction}

Dairy products, and in recent years, yoghurt in particular, are important components of the human diet. For this reason, manufacturers of dairy products are making an effort to meet the needs and expectations of the contemporary consumer by offering a growing assortment of products [1,2]. Consumers increasingly consider the quality of fermented milk products [3-5], and expect a high level of innovation. Chemically, yoghurt is a complex gel system incorporating protein, lipids, and polysaccharide in its structure. According to the definition given by the FAO/WHO, yoghurt is milk that has been fermented and coagulated using Lactobacillus delbrueckii subsp. bulgaricus and Streptococcus thermophilus bacteria [6]. It 
should be mentioned that Str. thermophilus bacteria primarily produce lactic acid, while L. delbrueckii subsp. bulgaricus are responsible for the aroma of yoghurt [7-9]. Lactic acid fermentation is one of the oldest and most widespread methods for preserving milk.

Among the food, yoghurt most frequently contains probiotics [10], which are defined as "live microorganisms, which when administered in adequate amounts confer a health benefit on the host" [11]. Lactic acid bacteria, mainly from the genera Bifidobacterium and Lactobacillus, are widely recognised as probiotics, as they commonly possess probiotic characteristics. These genera are usually assigned the generally-recognised-as-safe (GRAS) status, which indicates low or no health risk to the host upon consumption, with positive health effects $[10,12,13]$. Probiotic bacteria that are added to yoghurts colonize the human gut, thereby increasing immunity, reducing the effects of lactose intolerance, and protecting against diarrhoea and constipation. They also facilitate the absorption of minerals (iron and calcium) and vitamins $[12,14]$. Yoghurt is recommended for children, people with allergies or digestive disorders, the elderly, and patients undergoing antibiotic treatment $[12,14-16]$. The human body digests yoghurt three times faster than milk [17].

Producers increasingly often meet the expectations of consumers and enrich fermented milk beverages with plant additives. The application of additives primarily affects the sensory features of the final product, i.e., flavour, aroma, colour, and consistency, as well as texture and storage capacity. According to the idea of functional food, a plant additive also increases the content of bioactive compounds. When assessing the perceived quality of fermented dairy products, the most important are consumer quality attributes, i.e., sensory characteristics, mainly flavour, as well as availability, especially packaging and convenience of use, which determine the purchase decision. Healthiness, including product composition, is becoming increasingly important, especially among more informed consumers, taking into account not only the basic nutritional value, but also the content of biologically active ingredients positively influencing the human body. Therefore, fermented milk drinks enriched with plant additives may be more attractive to consumers, also contributing to increasing the market offer $[2,4]$.

In the recent years, it has been reported that fortification of yoghurts using natural resources (fruits, vegetables, cereals, nuts, seeds, oil, botanical or herbal extracts, fibre from fruits or vegetables, fruit processing wastes, and whey protein isolates) is necessary to improve its quality and bioactivity, including nutrient intake with minimal health side effects [2,18-20]. However, the base is natural, plain yoghurt, which should be of good quality.

In our research, we proposed sea buckthorn (Hippophae rhamnoides L.) as a new yoghurt additive. Sea buckthorn was known already in ancient Greece, where it was used as a medicine for horses. Its Latin name comes from Greek (hippos-horse, phao-shine). The treatment consisted of giving the animal leaves and young shoots of sea buckthorn, thanks to which the horses quickly gained mass and their fur was shiny [21]. Currently, sea buckthorn grows in Asia and Europe, including the Baltic Sea coast. It is cultivated on an industrial scale in Russia, Germany, China, Estonia, and Finland. In Poland, sea buckthorn can be found growing wild on the coast of the Baltic Sea, and there are few, small plantations of this plant in the rest of the country. Sea buckthorn belongs to the olive family and its fruits are drupes. Sea buckthorn berries are soft, elispoid, juicy, fine, and orange in colour, densely covering the shoots with a characteristic citrus aroma. It is a plant of increasing importance because of the content of numerous biologically active components. The extract content in the fruit ranges from 8.67 to $10.17 \%$. It is characterized by a high content of vitamins C, A, B1, B2, K, and PP; a precursor of folic acid; and high antioxidant activity (because of the presence of numerous anthocyanins, flavonoids, and polyphenols). Sea buckthorn berry is one of the few fruits that contains $3.67-6.17 \%$ fat. The total fat content depends on the variety and degree of fruit ripeness. The presence of fat means that fruits can be used to obtain oil and fatty acids present in it, the content of which is approximately $77 \%$, of which unsaturated acids constitute from $50 \%$ to even $70 \%$ of all fatty acids. Among the active substances, one can also distinguish carotenoids $(7.94-28.16 \mathrm{mg} / 100 \mathrm{~g})$, which 
give the fruit its characteristic colour. The fruit is also a valuable source of amino acids and minerals. Substances obtained from sea buckthorn berries exhibit antioxidant, antitumor, hepatoprotective, or immunomodulating activity [22-25]. Sea buckthorn preparations are used in the food, cosmetic, and pharmaceutical industries. In Poland, sea buckthorn is a still underrated raw material. The unique chemical composition of sea buckthorn allows it to act as a preservative and additive, as well as an ingredient improving the nutritional quality of the product.

So far, only a few studies have been published proposing the use of sea buckthorn in dairy products, including its fruit in cheese [26] and yoghurt [25,27-29]. These are papers aimed at assessing the acidity, nutritional value, and content of bioactive compounds. In the current study, particular attention was paid not only to the nutritional value, but also to sensory attractiveness, including an extensive picture of the structure. Great attention is paid to these very features when designing new products. Moreover, a new form of filling has been proposed, i.e., fruit mousse. Therefore, the aim of the study was to evaluate the nutritional value, microbiological quality, sensory properties, and structure of natural probiotic yoghurts made with the addition of sea buckthorn fruit mousse during refrigerated storage.

\section{Materials and Methods}

\subsection{Research Material}

The organic milk for yoghurt production was obtained from the dairy located in Jasienica Rosielna in southern Poland (mountainous areas). Raw material was delivered mainly from the Simmental breed raised on the certified local farms. Milk was normalized (3.2\% fat content) and pasteurized (very high temperature (VHT) pasteurization: $85^{\circ} \mathrm{C}$ for 20-25 s). Milk was collected two times in the spring/summer (pasture) season. It was transported to the laboratory under refrigeration and immediately used for analysis and yoghurt production.

\subsection{Milk Analysis}

\section{Acidity and Basic Composition}

In each sample of milk, the following parameters were determined: active acidity ( $\mathrm{pH}$ value), by $\mathrm{pH}$-meter $\mathrm{CP}-401$ (Elmetron, Poland); potential acidity (in ${ }^{\circ} \mathrm{SH}$ ), titration method according to Polish Standard PN-68/A-86122 [30]; contents of fat, total protein, lactose, and dry matter, using the infrared spectroscopy method by infrared milk analyzer (Bentley Instruments, Chaska, MN, USA); somatic cell count (SCC) using the flow cytometry method, Somacount 150 apparatus (Bentley, Chaska, MN, USA); and casein percentage according to the Association of Official Agricultural Chemists (AOAC) [31].

The total bacterial count (TBC) in the raw milk was determined (according to Polish Standard [32]) in order to verify whether it met the requirements for microbiological quality $(\mathrm{TBC}<100,000 / \mathrm{mL})$.

\subsection{Yoghurt Production}

The yoghurts were produced by the water bath method (the thermostatic method). Ten (10) litres of milk was heat-treated to $43^{\circ} \mathrm{C}$ and the sea buckthorn mousse was added at a rate of $5 \%$. The mousse is produced at a small processing facility (Sea buckthorn and Friends Producer, Warsaw, Poland) from its own raw material. Whole sea buckthorn fruits are grated together with the seeds. Then, the water is evaporated at low temperature $\left(32^{\circ} \mathrm{C}\right)$ and reduced pressure in order to thicken the product. The blended mix was inoculated with starter strains of yoghurt bacteria from Chr. Hansen (Denmark) in the amount of $0.15 \mathrm{~g} / \mathrm{L}$ [15]. Thermophilic, probiotic starter yoghurt cultures, i.e., FD-DVS ABT-1, based on Lactobacillus acidophilus LA-5, Bifidobacterium lactis BB-12, and Streptococcus thermophilus, were used to yoghurt production. The blended mix was portioned into $100 \mathrm{~mL}$ plastic containers and incubated $6 \mathrm{~h}$ until $\mathrm{pH}=$ approximately 4.6 was attained. The products 
were then cooled to $20{ }^{\circ} \mathrm{C}$ to discontinue the incubation. The yoghurts were stored at $4-6^{\circ} \mathrm{C}$ until the next day (approximately $14 \mathrm{~h}$ ) for analysis.

The yoghurts were retested every 7 days, for 21 days (day 0,7 th, 14th, and 21st). The yoghurts were stored in the closed cups under refrigerated conditions $\left(4-6{ }^{\circ} \mathrm{C}\right)$. A new cup was opened at each stage.

The description of yoghurt samples is presented in Table 1.

Table 1. The description of yoghurt samples.

\begin{tabular}{cc}
\hline Characteristic & Description \\
\hline Milk type & Organic \\
Season of milk production & Spring/summer (pasture) season \\
Milk thermal treatment & Very high temperature (VHT) pasteurization $\left(85^{\circ} \mathrm{C}\right.$ for \\
Addition & $20-25 \mathrm{~s})$ \\
Starter strains of yoghurt bacteria & Sea buckthorn mousse $(5 \%)$ \\
Yoghurt type & Thermophilic, probiotic starter yoghurt cultures, i.e., ABT-1 \\
& $(0.15$ g/L) \\
Plain, natural yoghurt \\
Day of storage & 0 \\
& 7 \\
& 14 \\
& 21 \\
\hline
\end{tabular}

\subsection{Yoghurt Analysis}

\subsubsection{Acidity and Nutritional Value}

The potential acidity $\left({ }^{\circ} \mathrm{SH}\right)$ was determined by the titration method [33] and expressed as the content of lactic acid (\%). The yoghurts were analysed for content of protein (Kjeldahl method [34]), fat (van Gulik's method), and dry matter (oven-drying at $102{ }^{\circ} \mathrm{C}$ ) [33]. The measurements were taken in triplicate.

\subsubsection{Sensory Evaluation}

Sensory evaluation of yoghurts was carried out using the scaling method. A sensory evaluation of the yoghurts was performed by a suitably prepared twenty-person panel. All persons were trained according to recommendations pertaining to the scaling method used. Prior to the evaluation, the samples were coded and left to stand for $1 \mathrm{~h}$ at room temperature to reach a suitable temperature for eating, and then they were presented to the testers together with a questionnaire. A five-point scale was used to evaluate the colour, consistency, flavour, aroma, and general acceptance of the products, in which 1 designated disqualifying quality (unsuitable) and 5 indicated very good quality (natural, characteristic for the product) [35]. The studies were performed taking into account the requirements for fermented milk [33].

\subsubsection{Microbiological Evaluation}

Each sample of yoghurt was homogenized prior to testing; subsequently, $10 \mathrm{~g}$ of material was measured and placed in sterile bottles containing $90 \mathrm{~mL}$ of Ringer's solution [36,37]. The solution was shaken for $5 \mathrm{~min}$ and allowed to sediment for $15 \mathrm{~min}$. Then, a series of ten-fold dilutions of the samples were prepared in Ringer's solution and spread onto previously prepared Petri dishes with an appropriate microbiological medium. The following was determined in each material: total number of mesophilic aerobic bacteria on enriched agar medium for $48 \mathrm{~h}$ at $30^{\circ} \mathrm{C}$ (BTL Ltd., Warsaw, Poland) according to PN-ISO 7889:2007 [38]; total number of fungi on Sabouraud medium for 5-7 days at $30{ }^{\circ} \mathrm{C}$ (BTL Ltd., Warsaw, Poland.) [39]; total number of coliform bacteria on Endo les medium for $24 \mathrm{~h}$ at $37^{\circ} \mathrm{C}$ (BTL Polska Sp. z o.o.) [38]; total number of fecal Escherichia coli on mFC medium for 18-24 h at $44^{\circ} \mathrm{C}$ (BTL Ltd., Warsaw, Poland) [40]; total number of Clostridium perfringens, sulfate reducing bacteria (IV) growing in anaerobic conditions on the Iron Sulfide Agar 
(TSC) for $48 \mathrm{~h}$ at $37^{\circ} \mathrm{C}$ (Biomerieux Poland Ltd., Warsaw, Poland) [41]; total number of lactic acid bacteria of the genus Lactobacillus sp. on the De Man, Rogosa and Sharpe Medium Agar-MRS medium for 3-5 days at $30^{\circ} \mathrm{C}$ (BTL Ltd., Warsaw, Poland) [42]; bacilli of the genus Listeria sp. on the Listeria Selective Medium Agar-LSA medium (Merck, Darmstadt, Germany); total number of bacteria of the genus Bifidobacterium sp. on the Bifidus Selective Medium Agar-BSM medium (Sigma-Aldrich, St. Louis, MO, USA) [43]; and presence of Salmonella bacilli on the Salmonella-Shigella Medium Agar-SS medium and Xylose Lysine Deoxycholate Agar-XLD) after prior sample multiplication in buffered peptone water and Rappaport-Vassiliadis medium (BTL Ltd., Warsaw, Poland) for $24 \mathrm{~h}$ at $37^{\circ} \mathrm{C}$. Final identification was performed using the available API tests (BioMerieux Poland Ltd., Warsaw, Poland) and polyvalent sera (Biomed S.A.) [44].

Each previously prepared sample was plated in triplicate. After incubation, the colonies were counted using an automatic Scan 300 counter (Inrerscience Laboratories, Saint-Nom-la-Bretèche, France) and the number of individual morphological types was counted as the number of colony forming units in $1 \mathrm{~g}$ of the yoghurt (cfu/g).

\subsubsection{Microstructure Analysis}

A yoghurt sample $(0.25 \mathrm{~g})$ was mixed with an equal weight of $2.5 \%$ aqueous agar. Then, it was rested to solidify by cooling at room temperature. After the formation of a stabile gel, the samples were cut into specimens with $2 \times 2 \times 2 \mathrm{~mm}$ using a surgery lancet and immersed in $4 \%$ glutaraldehyde (prepared using a $1.0 \mathrm{M}$ phosphate buffer, $7.0 \mathrm{pH}$ ) solution overnight. The fixed specimens were washed twice ( 5 min each time) using phosphate buffer ( $\mathrm{pH} 7.0$ ) and then dehydrated in a graded ethanol series of 30, 50, 70, 90, 96, and $99.8 \%$ for 20 min intervals. The samples were critical-point dried using a critical point dryer (model Emitech K850, Quorum Technologies Ltd., Sussex, UK) and pieces with reduced height were mounted on the aluminum stubs. The mini-cubes were coated with a thin layer of gold in a sputter coater (model Emitech K550X, Quorum Technologies Ltd., Sussex, UK) and transferred into a high-vacuum scanning electron microscope (Tescan VEGA $\backslash \backslash$ LMU, Brno, Czech Republic). Measurements using the scanning electron microscope were carried out at $30 \mathrm{kV}$ and images were recorded at 200, 1000, and $3500 \times$ magnifications. The evaluation was taken in triplicate.

\subsubsection{FTIR Measurements}

Measurements of Attenuated Total Reflection FTIR (ATR-FTIR) background-corrected spectra (25 scans for each sample) were carried out with the use of an HATR Ge through a crystal plate $\left(45^{\circ}\right.$ cut, yielding 10 internal reflections) at $20{ }^{\circ} \mathrm{C}$, and were recorded with a 670-IR spectrometer (Agilent, Santa Clara, CA, USA). The Ge crystal was cleaned with ultra-pure organic solvents (Sigma-Aldrich, St. Louis, MO, USA). The instrument was continuously purged with argon for $40 \mathrm{~min}$. before and during the measurements. Absorption spectra, at a resolution of one data point per $1 \mathrm{~cm}^{-1}$, were obtained in the region between 4000 and $600 \mathrm{~cm}^{-1}$. Scans were Fourier-transformed and averaged with Grams/AI 8.0 software (Thermo Fisher Scientific, Waltham, MA, USA). The methodology was developed on the basis of Ahmed et al. [45] and Chen et al. [46].

\subsection{Statistical Analysis}

Statistical analysis of the results was performed using in StatSoft Inc. Statistica ver. 13.1 (Dell, Round Rock, TX, USA), by one- and multi-way analysis of variance (ANOVA). Homogeneity of variance was tested by Levene's test and the Brown-Forsythe test. Significance of differences was determined at a level of $p$ (alpha) $=0.05$ and 0.01 . The results are presented as mean \pm standard deviation (SD). 


\section{Results}

\subsection{Basic Physico-Chemical Parameters in Milk}

The evaluation of nutritional value of pasteurized organic milk showed that it contained $12.16 \%$ dry matter, including $3.06 \%$ crude protein, $3.20 \%$ fat, and $4.75 \%$ lactose (Table 2). The acidity of milk, expressed as active acidity ( $\mathrm{pH}$ value) and potential acidity (titrimetric, in ${ }^{\circ} \mathrm{SH}$ ), was 6.70 and $6.82{ }^{\circ} \mathrm{SH}$, respectively. The number of somatic cells, proving the cytological quality, amounted to 61 thous. $/ \mathrm{mL}$ of milk. The total bacteria count was not detected $(0 \mathrm{cfu} / \mathrm{mL})$.

Table 2. Results of physico-chemical analysis of pasteurized organic milk obtained from the dairy used in the production of yoghurts (mean $\pm \mathrm{SD}$ ).

\begin{tabular}{ccccccc}
\hline $\begin{array}{c}\text { Active } \\
\text { Acidity } \\
(\mathbf{p H})\end{array}$ & $\begin{array}{c}\text { Potential } \\
\text { Acidity } \\
\left({ }^{\circ} \mathbf{S H}\right)\end{array}$ & $\begin{array}{c}\text { Total } \\
\text { Protein } \\
(\mathbf{\%})\end{array}$ & $\begin{array}{c}\text { Casein } \\
\mathbf{( \% )}\end{array}$ & $\begin{array}{c}\text { Fat } \\
(\mathbf{\%})\end{array}$ & $\begin{array}{c}\text { Lactose } \\
\mathbf{( \% )}\end{array}$ & $\begin{array}{c}\text { Dry Matter } \\
(\mathbf{\%})\end{array}$ \\
\hline $6.70 \pm 0.05$ & $6.82 \pm 0.08$ & $3.06 \pm 0.10$ & $2.48 \pm 0.08$ & $3.25 \pm 0.08$ & $4.75 \pm 0.06$ & $12.16 \pm 0.15$ \\
\hline
\end{tabular}

\subsection{Yoghurts}

\subsubsection{Acidity}

The initial active acidity in pure natural yoghurts was 4.64 , while it was 4.58 with the addition of sea buckthorn (Figure 1). Thus, the applied plant additive had a significant effect on yoghurt acidity, i.e., it lowered the initial $\mathrm{pH}$ value $(p \leq 0.05)$. The acidity of both products generally decreased with time (increase in $\mathrm{pH}$ on day 7 of storage followed by a gradual decrease). Changes also concerned potential acidity expressed as lactic acid content (Figure 2). Yoghurt without addition contained $0.72 \%$ lactic acid, and that with sea buckthorn contained $0.69 \%$, and the difference was not statistically significant.

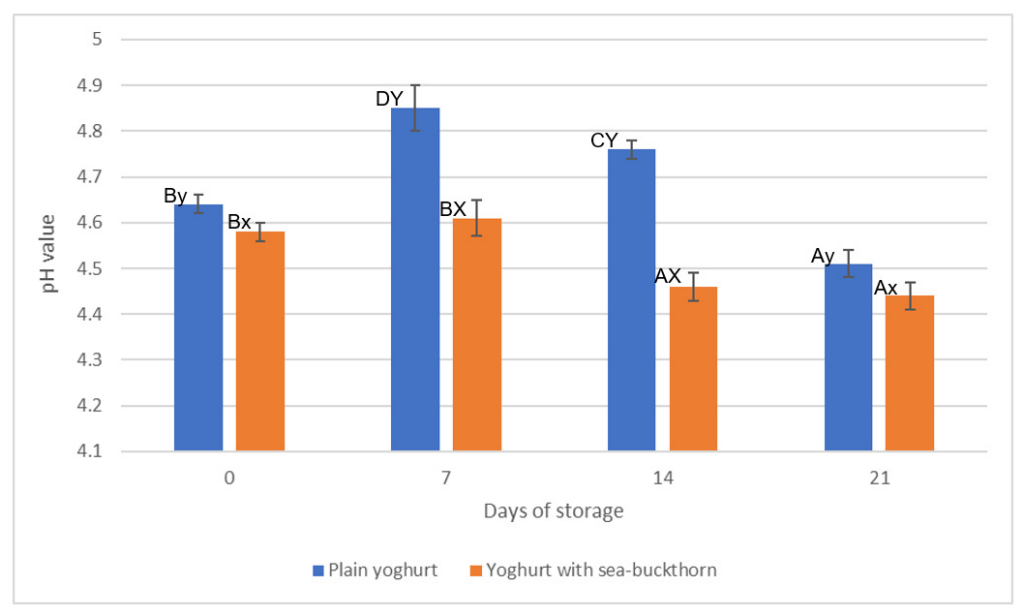

Figure 1. Changes of $\mathrm{pH}$ value in the analysed yoghurts during 21 days of storage in the refrigerated conditions. A, B, C, D-differences between the $\mathrm{pH}$ value within a yoghurt type, significant at $p \leq$ 0.01. $\mathrm{x}, \mathrm{y}, \mathrm{X}, \mathrm{Y}$ - differences between days of storage regardless of yoghurt type; $\mathrm{x}, \mathrm{y}$-significant differences at $p \leq 0.05 ; \mathrm{X}, \mathrm{Y}$ - significant differences at $p \leq 0.01$.

\subsubsection{Nutritional Value}

The results of the basic nutritional value assessment are presented in Table 3. Products containing mousse additive were characterized by a higher dry matter content, including total protein and fat. However, it should be noted that the differences between yoghurt types were not statistically confirmed. It was demonstrated that, regardless of the presence of the additive (yoghurt type), the content of the mentioned components changed during the refrigerated storage, as it decreased in all cases. These differences were statistically significant within the type of yoghurt. In general, yoghurts with sea buckthorn mousse 
addition contained the highest dry matter content, including total protein and fat, on the initial day of storage-day " 0 ". Pure natural yoghurt was the poorest source of these components on the last (21st) day of storage.

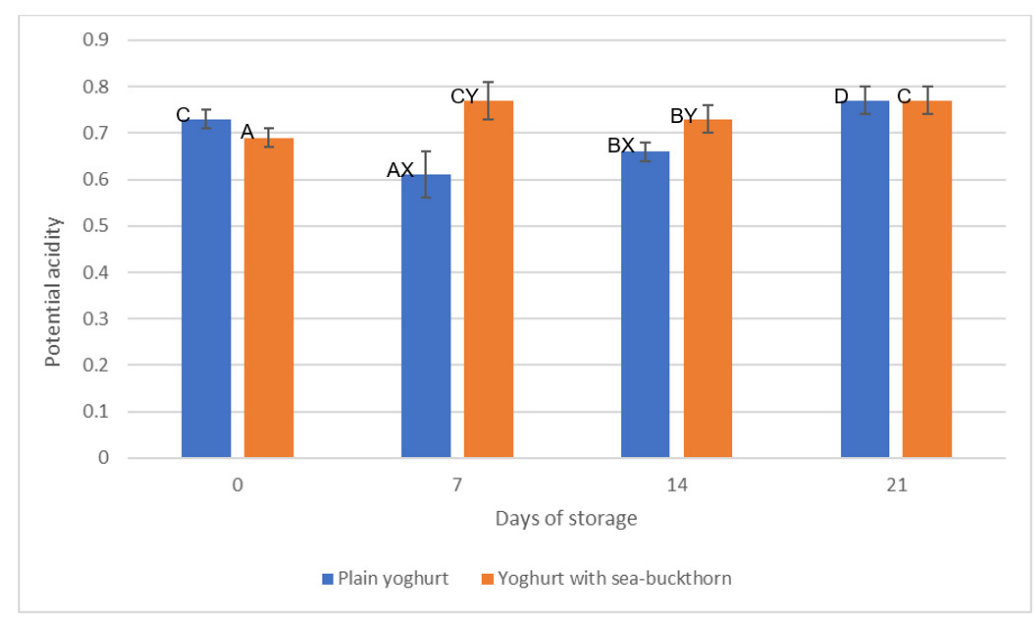

Figure 2. Changes of lactic acid content (\%) in the analysed yoghurts during 21 days of storage in the refrigerated conditions. A, B, C, D-differences between the lactic acid content within a yoghurt type, significant at $p \leq 0.01$. X, Y-differences between days of storage regardless of yoghurt type, significant at $p \leq 0.01$.

Table 3. Results of basic chemical composition analysis of yoghurts during 21 days of storage in the refrigerated conditions (mean $\pm \mathrm{SD}$ ).

\begin{tabular}{ccccc}
\hline Yoghurt Type & Day of Storage & $\begin{array}{c}\text { Total Protein } \\
\mathbf{( \% )}\end{array}$ & $\begin{array}{c}\text { Fat } \\
\mathbf{( \% )}\end{array}$ & $\begin{array}{c}\text { Dry Matter } \\
\mathbf{( \% )}\end{array}$ \\
\hline & 0 & $3.07^{\mathrm{b}} \pm 0.07$ & $3.24 \pm 0.08$ & $12.21^{\mathrm{B}} \pm 0.15$ \\
Plain, natural & 7 & $3.05^{\mathrm{ab}} \pm 0.10$ & $3.18 \pm 0.10$ & $12.08^{\mathrm{B}} \pm 0.20$ \\
yoghurts & 14 & $3.01^{\mathrm{ab}} \pm 0.14$ & $3.16 \pm 0.09$ & $11.49^{\mathrm{B}} \pm 0.18$ \\
& 21 & $2.80^{\mathrm{a}} \pm 0.15$ & $3.10 \pm 0.12$ & $10.10^{\mathrm{A}} \pm 0.23$ \\
\hline Yoghurts with & 0 & $3.11^{\mathrm{b}} \pm 0.10$ & $3.33^{\mathrm{b}} \pm 0.07$ & $12.38^{\mathrm{C}} \pm 0.19$ \\
sea buckthorn & 7 & $3.09^{\mathrm{ab}} \pm 0.13$ & $3.30^{\mathrm{b}} \pm 0.11$ & $12.20^{\mathrm{C}} \pm 0.17$ \\
fruit mousse & 14 & $3.04^{\mathrm{ab}} \pm 0.18$ & $3.23^{\mathrm{ab}} \pm 0.09$ & $11.64^{\mathrm{B}} \pm 0.20$ \\
& 21 & $2.82^{\mathrm{a}} \pm 0.16$ & $3.15^{\mathrm{a}} \pm 0.12$ & $10.29^{\mathrm{A}} \pm 0.23$ \\
\hline
\end{tabular}

$\mathrm{a}, \mathrm{b}, \mathrm{A}, \mathrm{B}, \mathrm{C}$ - differences between the basic chemical composition within a yoghurt type; $\mathrm{a}, \mathrm{b}-$ significant differences at $p \leq 0.05 ; \mathrm{A}, \mathrm{B}$ - significant differences at $p \leq 0.01$.

\subsubsection{Sensory Evaluation}

The results of sensory evaluation are shown in Figure 3a,b. Among all analysed variants (type of yoghurt and day of storage), the highest scores were given to yoghurt without sea buckthorn addition on the first day of the research, i.e., 5 points for colour, consistency, flavor, and aroma. On the other hand, the lowest $(4.03,4.25,4.40$, and 4.45 points, respectively) were obtained by yoghurt with the addition of sea buckthorn mousse on the last day, i.e., on the 21st day of storage. In general, yoghurt containing the additive, regardless of the day of storage, received statistically significantly $(p \leq 0.05)$ lower scores for all analysed characteristics. These results translated into a general acceptance note, as yoghurts without an additive obtained 4.81 points $/ 5$ points max, and those with mousse obtained 4.54 points. The least rated parameter was colour-yoghurts with mousse on day 21 of storage received 4.03 points. However, it should be emphasized that the results obtained for the yoghurts with the addition of sea buckthorn mousse were relatively high-above 4 points $/ 5$ points max for each characteristic. 


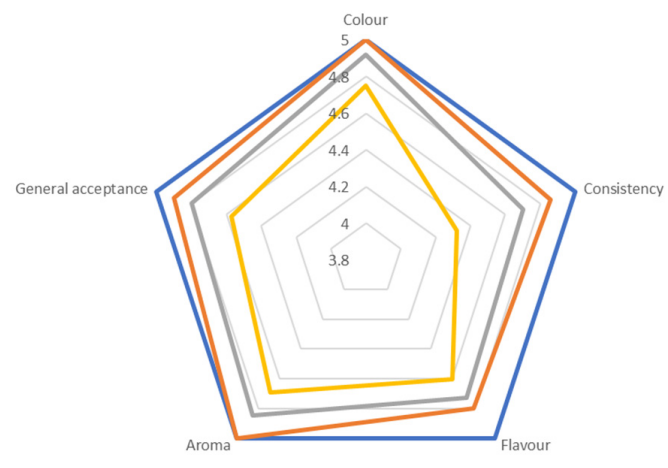

(a)

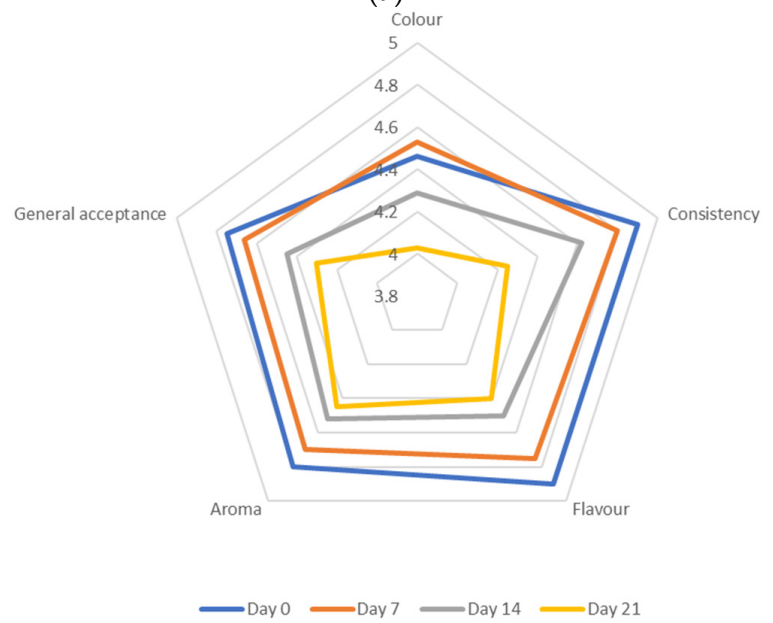

(b)

Figure 3. (a) Changes in sensory quality (colour, consistency, flavour, aroma, and general acceptance) of the plain, natural yoghurts during 21 days of storage in the refrigerated conditions. (b) Changes in sensory quality (colour, consistency, flavour, aroma, and general acceptance) of the yoghurts with sea buckthorn fruit mousse during 21 days of storage in the refrigerated conditions.

\subsubsection{Microbiological Evaluation}

Analysing the count of mesophilic aerobic bacteria, significant statistical differences were found in both the analysed yoghurt types and individual days of sample storage (Table 4). Plain, natural yoghurt showed the lowest abundance of this group of microorganisms on the day of starting the analyses. This value was statistically significantly lower than in the corresponding testing period of yoghurt with sea buckthorn mousse and other values obtained during the storage of material type $(p \leq 0.01)$. Statistical analysis of the results obtained from subsequent time points of microbiological experiments (day 7, 14, 21) did not show any significant effect of storage time on the number of mesophilic aerobic bacteria in the plain, natural yoghurt. On the other hand, the addition of sea buckthorn mousse had a statistically significant effect on the decrease in the concentration of the analysed group of microorganisms already on the 7th day of storage. This relationship was preserved and statistically confirmed on both day 14 and 21 of analyses at the level of statistical significance $(p \leq 0.01)$, where no increase in this group of microorganisms was observed. Yoghurts with the addition of sea buckthorn mousse were characterized by a statistically significantly higher level of yeast-like fungi development $(p \leq 0.01)$. However, no statistically significant differences in the number of these microorganisms were recorded throughout the storage period. No fungal growth was observed in plain, natural yoghurt at any of the analysis time points. The total number of lactic acid bacteria reached a high and similar concentration both in plain, natural yoghurt with sea buckthorn mousse 
addition, and the differences did not exceed the statistical significance threshold in any of the analysed materials. When analysing typical yoghurt flora, statistically significant differences were observed on the 7th day of storage between yoghurts in the number of bacteria of the genus Bifidobacterium sp. There was a statistically lower number of these microorganisms in the yoghurts enriched with sea buckthorn mousse $(p \leq 0.05)$.

\subsubsection{Microstructure Analysis}

The microstructure of the products was recorded using a scanning electron microscope (SEM) at various magnifications (Figure 4a-d). Yoghurt images showed a completely different microstructure of the yoghurt with sea-buckthorn (Figure 4c,d). The addition of sea-buckthorn to yoghurt contributed to the production of a gel during fermentation, stabilized by a greater number of bonds. On the other hand, yoghurt without the addition of sea buckthorn (Figure $4 a, b$ ) had smaller clusters of casein micelles, thick chains, and smaller and less frequent empty spaces. Faster degradation rate of yoghurt with the addition of sea buckthorn compared with yoghurt without the additive could also be observed after three weeks of storage of yoghurts in refrigerated conditions (Figure 4a,b). The yoghurt with the addition of sea buckthorn after 21 days of refrigerated storage lost its initial structure faster compared with the yoghurt on day 0 and yoghurt without the addition of sea buckthorn.

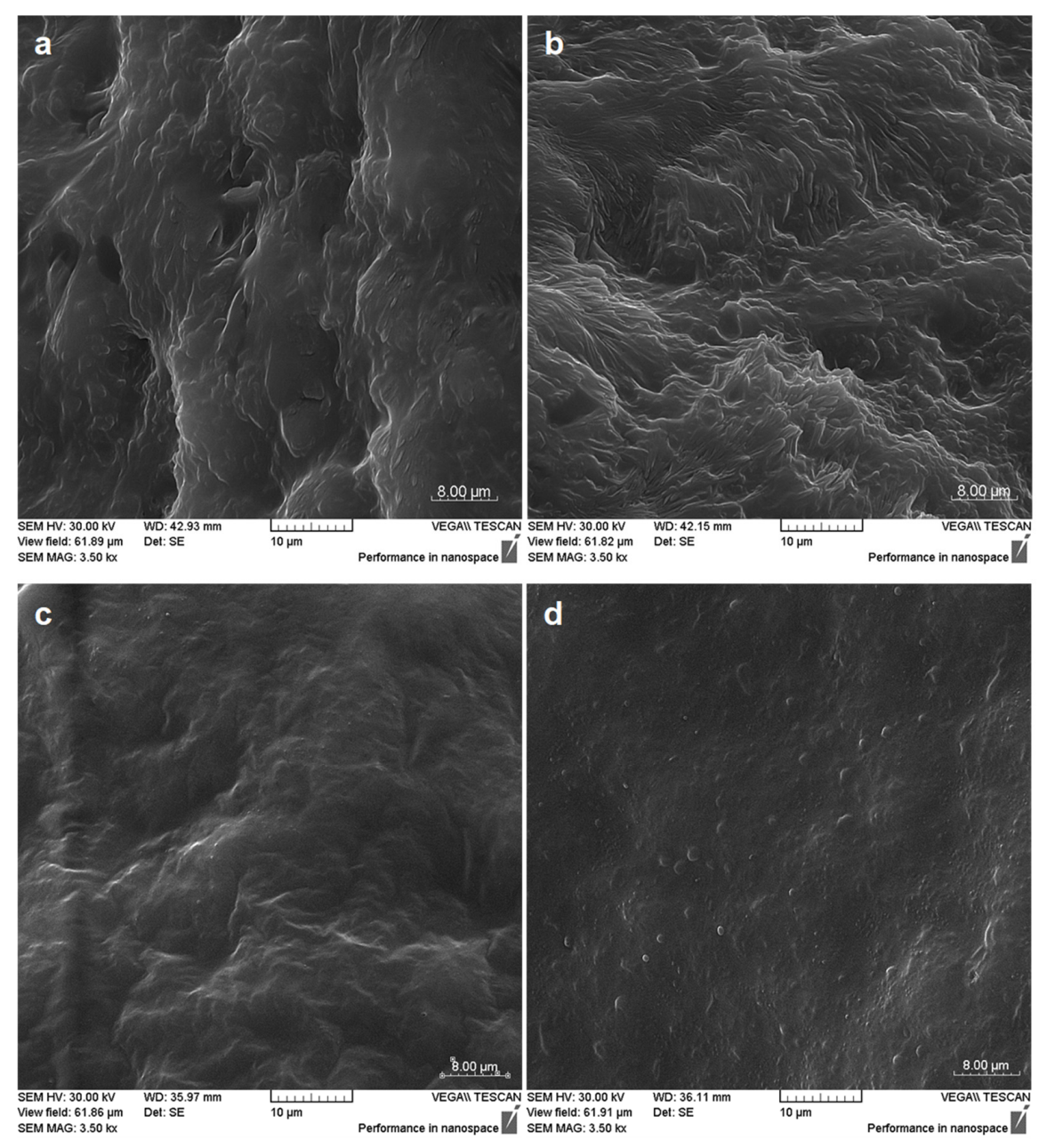

Figure 4. Scanning electron microscopy (SEM) of yoghurts, magnification $3500 \times$. Microstructure: (a) the plain, natural yoghurt during 0 day of storage in the refrigerated conditions; (b) the plain, natural yoghurt during 21 days of storage in the refrigerated conditions; (c) the yoghurt with sea buckthorn mousse during 0 day of storage in the refrigerated conditions; (d) the yoghurt with sea buckthorn mousse during 21 days of storage in the refrigerated conditions. 
Table 4. Microbiological evaluation of the analysed yoghurts during 21 days of storage in the refrigerated conditions.

\begin{tabular}{|c|c|c|c|c|c|c|c|c|c|c|}
\hline Yoghurt Type & $\begin{array}{l}\text { Day of } \\
\text { Storage }\end{array}$ & $\begin{array}{c}\text { Total } \\
\text { Bacterial } \\
\text { Count }\end{array}$ & $\begin{array}{l}\text { Total Number } \\
\text { of Fungi }\end{array}$ & $\begin{array}{c}\text { Total Number } \\
\text { of Lactic Acid } \\
\text { Bacteria }\end{array}$ & $\begin{array}{l}\text { Total Number } \\
\text { of Bacteria of } \\
\text { the Genus } \\
\text { Clostridium sp. }\end{array}$ & $\begin{array}{c}\text { Total } \\
\text { Number of } \\
\text { Coli } \\
\text { Bacteria } \\
\text { (Endo) }\end{array}$ & $\begin{array}{c}\text { Total } \\
\text { Number of } \\
\text { Faecal } \\
\text { Coliforms } \\
\text { (mFC) }\end{array}$ & $\begin{array}{l}\text { Total Number of } \\
\text { Bacteria of the } \\
\text { Genus } \\
\text { Bifidobacterium sp. }\end{array}$ & $\begin{array}{c}\text { Presence of } \\
\text { Salmonella } \\
\text { Bacilli }\end{array}$ & $\begin{array}{c}\text { Presence of } \\
\text { Campylobacter } \\
\text { Bacilli }\end{array}$ \\
\hline \multirow{4}{*}{$\begin{array}{l}\text { Plain, natural } \\
\text { yoghurts }\end{array}$} & 0 & $<1.5 \times 10^{1 \mathrm{~A}}$ & 0 * & $8.2 \times 10^{7}$ & 0 & 0 & 0 & $7.6 \times 10^{6}$ & 0 & 0 \\
\hline & 7 & $8.0 \times 10^{5 \mathrm{~B} * *}$ & 0 * & $5.6 \times 10^{7}$ & 0 & 0 & 0 & $1.6 \times 10^{7} *$ & 0 & 0 \\
\hline & 14 & $2.2 \times 10^{6 B} * *$ & 0 * & $4.7 \times 10^{7}$ & 0 & 0 & 0 & $2.4 \times 10^{6}$ & 0 & 0 \\
\hline & 21 & $3.2 \times 10^{5 \mathrm{~B} * *}$ & 0 * & $6.7 \times 10^{7}$ & 0 & 0 & 0 & $3.1 \times 10^{7}$ & 0 & 0 \\
\hline \multirow{4}{*}{$\begin{array}{l}\text { Yoghurts with } \\
\text { sea buckthorn } \\
\text { fruit mousse }\end{array}$} & 0 & $4.5 \times 10^{1 \mathrm{~B}}$ & \multirow{4}{*}{$\begin{array}{c}7.2 \times 10^{2 * *} \\
<1.0 \times 10^{2} * * \\
<1.0 \times 10^{2} * * \\
1.0 \times 10^{4 * *} \\
\text { yeast }\end{array}$} & $8.1 \times 10^{7}$ & 0 & 0 & 0 & $7.8 \times 10^{7}$ & 0 & 0 \\
\hline & 7 & $<1.5 \times 10^{1 \mathrm{~B} * *}$ & & $8.9 \times 10^{7}$ & 0 & 0 & 0 & $7.2 \times 10^{5 *}$ & 0 & 0 \\
\hline & 14 & $0^{\mathrm{A} * *}$ & & $8.2 \times 10^{7}$ & 0 & 0 & 0 & $1.2 \times 10^{6}$ & 0 & 0 \\
\hline & 21 & $0^{A} * *$ & & $5.1 \times 10^{7}$ & 0 & 0 & 0 & $2.9 \times 10^{7}$ & 0 & 0 \\
\hline
\end{tabular}

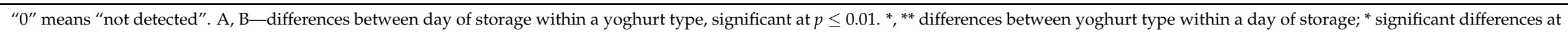
$p \leq 0.05 ;{ }^{* *}$ significant differences at $p \leq 0.01$. 


\subsubsection{FTIR Measurements}

Figure 5 presents the FTIR absorption spectra measurements for the yoghurt samples selected for testing: plain, natural probiotic (black line in each panel), and probiotic yoghurt with sea buckthorn mousse (red line in each panel). A comparative analysis of the spectra was conducted at every stage of the study to identify spectroscopic differences in the initial phase between the selected samples. Secondly, the spectra were also collected at weekly intervals in order to find spectroscopic markers of aging. The samples were placed on an HATR Ge crystal and tested under an $\mathrm{N}_{2}$ atmosphere (as explained in the Materials and Methods section). Table 5 presents all the characteristic bands recorded in the selected samples, as well as those of the corresponding functional groups identified based on a detailed review of the available and plentiful literature data. It is worth noting that all FTIR infrared spectra analysed in the study of the yoghurt samples, for both plain probiotic yoghurt and probiotic yoghurt with sea buckthorn mousse, had very intense and distinct bands that could be quite precisely attributed to the specific vibrations of functional groups present in ingredients typical of this type of food product. Additionally, for ease of comparison and interpretation, the spectra were normalized at an approximate wavelength of $3280 \mathrm{~cm}^{-1}$. The spectra of all the tested yoghurts showed very similar absorption bands, consistent with literature reports, which indirectly also proved their good quality. We observed only slight differences in specific spectral regions within individual samples, and the differences progressively decreased over the course of the study - the biggest differences occurred at the very beginning of the experiment. The bands characteristic of the $v(-\mathrm{OH})$ stretching vibrations, occurring as a very wide band with a maximum at about $3280 \mathrm{~cm}^{-1}$, could be clearly observed $[45,47]$. They might originate from the small amounts of water present in the tested samples and, above all, from the constituent sugar residues. Another very important area of vibrations, with the maximum at between 3000 and about $2800 \mathrm{~cm}^{-1}$, is often called the fatty acid region for this type of sample. The bands with the maxima at around 2923 and $2853 \mathrm{~cm}^{-1}$ are asymmetric vibrations of the C-H methylene group in the cholesterol structure [45,47-49]. Vibrations of this group cause stretching vibrations of $\mathrm{CH}_{2}$ and $\mathrm{CH}_{3}$ groups of fatty acids present in yoghurt samples. In turn, symmetrical vibrations in these groups were reflected in a sharp band with the maximum at $2956 \mathrm{~cm}^{-1}$. All yoghurt samples tested at identical time intervals showed distinct vibrations in this region. The next very sharp and very distinct band with the maximum at approximately $1744 \mathrm{~cm}^{-1}$ was most likely related to stretching vibrations of the $\mathrm{C}=\mathrm{O}$ carbonyl group, derived from a fragment of the ester group or carboxylic acids [50-52]. For all tested samples, the band was quite important and provided important information, even after normalizing the spectra at the wave number related to the stretching vibrations of the $-\mathrm{OH}$ group. The region between 1700 and $1240 \mathrm{~cm}^{-1}$ is very important in the description and interpretation of this type of sample, as it is a heterogeneous area containing vibration bands characteristic mainly of fatty acids, protein molecules, and polysaccharides. The band with the maximum at between 1535 and approximately $1570 \mathrm{~cm}^{-1}$ for protein was derived from the vibration of amide II, while between $\sim 1620$ and $1690 \mathrm{~cm}^{-1}$ was from amide I structural vibration $[43,48]$. Amide I vibrations were represented mainly by stretching vibrations of the amide $\mathrm{C}=\mathrm{O}$ group coupled with in-plane stretching vibrations of the $\mathrm{N}-\mathrm{H}$ group and stretching vibrations of the $\mathrm{C}-\mathrm{N}$ group. Overall, this area did not differ significantly between the two types of yoghurt, and the observed slight differences disappeared very rapidly during the experiment. Clear differences between the samples were observed only in the third week of the experiment. On the other hand, the area ranging from 1150 to $1000 \mathrm{~cm}^{-1}$ was dominated by bands originating from polysaccharide systems [52-55]. This location looked different for the sample of probiotic yoghurt containing sea buckthorn mousse, especially in the initial stage of the experiment. 


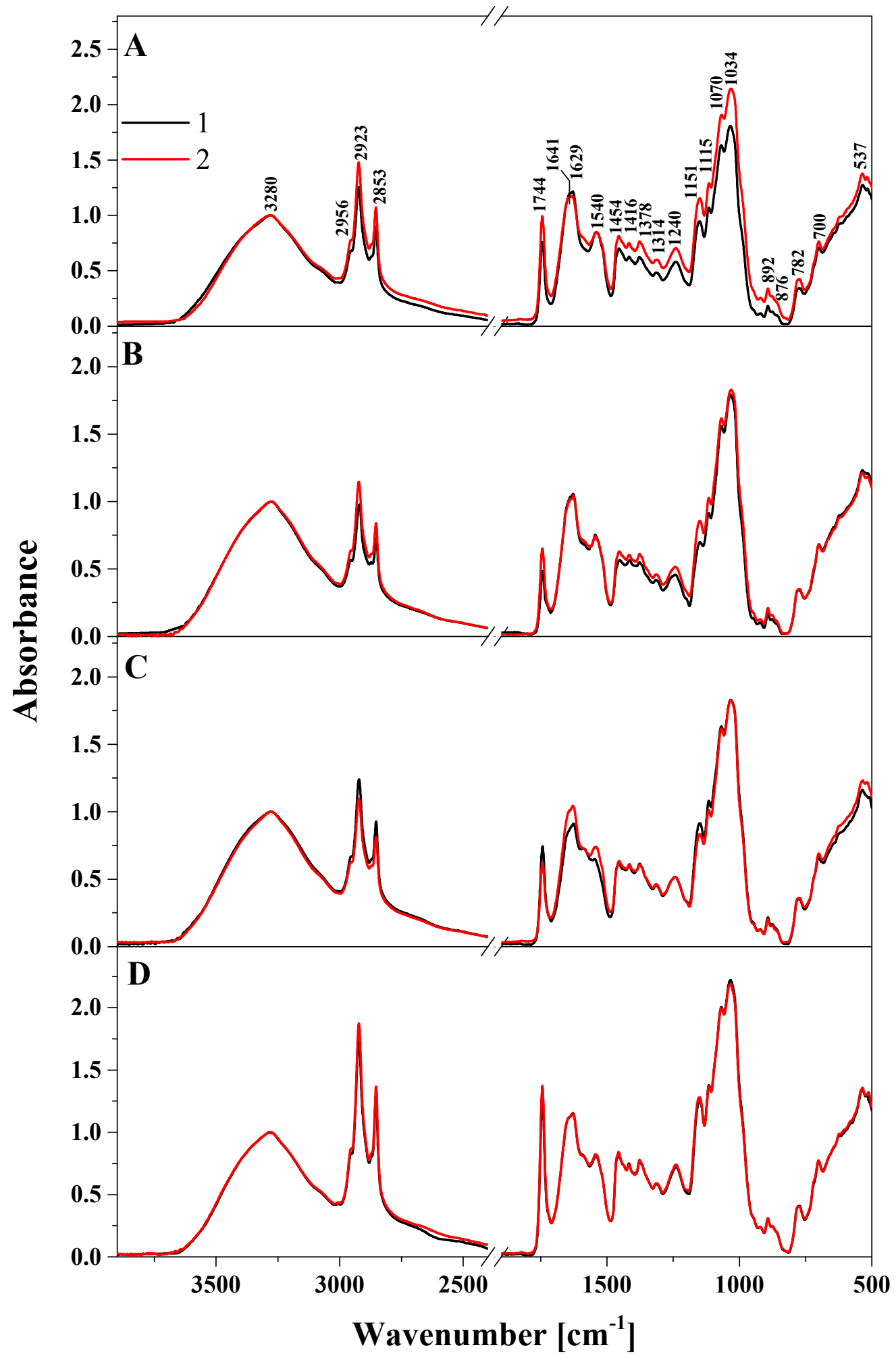

Figure 5. Panel (A)—28.09 ("0" day of storage), panel (B) - 5.10 ("7" day of storage), panel (C) - 12.10 ("14" day of storage), and panel (D)—19.10 (“21" day of storage). Black line—plain, natural probiotic yoghurt; red line-probiotic yoghurt with sea buckthorn mousse. 
Table 5. The location of the maxima of the Fourier Transform Infrared (FTIR) absorption bands, with assignment of particular vibrations to the respective samples, registered within the spectral range of $700-3700 \mathrm{~cm}^{-1}[45,47-59]$.

\begin{tabular}{|c|c|}
\hline FTIR & Type and Origin of Vibrations \\
\hline 3280 & $v(-\mathrm{O}-\mathrm{H})$ \\
\hline 2956 & \\
\hline 2923 & $v\left(-\mathrm{CH}_{2}\right)$ and $v\left(-\mathrm{CH}_{3}\right)$, s and as \\
\hline 2853 & \\
\hline 1744 & $v(-\mathrm{C}=\mathrm{O})$ in esters or carboxylic acid \\
\hline 1641 & amide I oraz $\delta(-\mathrm{OH})$ \\
\hline 1629 & $(v(\mathrm{C}=\mathrm{O})+v(\mathrm{~N}-\mathrm{H})$ in-plane and $\delta(\mathrm{C}-\mathrm{N}))$ \\
\hline 1540 & \multirow{5}{*}{$\begin{array}{l}\text { amide II, fatty acids, proteins, and polisacharides } \\
(v(C=C) \text { of nonconjugated trans and cis-lipids etc. })\end{array}$} \\
\hline 1416 & \\
\hline 1378 & \\
\hline 1314 & \\
\hline 1240 & \\
\hline 1151 & \multirow{4}{*}{ polisacharides $(\nu(\mathrm{C}-\mathrm{O}-\mathrm{C})$ and $\nu(\mathrm{C}-\mathrm{O}))$} \\
\hline 1115 & \\
\hline 1070 & \\
\hline 1034 & \\
\hline 892 & \multirow{5}{*}{$\alpha$-glycosidic bond } \\
\hline 876 & \\
\hline 782 & \\
\hline 700 & \\
\hline 537 & \\
\hline
\end{tabular}

\section{Discussion}

\subsection{Basic Physico-Chemical Parameters in Milk}

According to Codex Alimentarius [60], the titratable acidity, microbiological, and chemical criteria should be used to detect unacceptable conditions in milk products. Titrimetric acidity expresses the degree of buffering of milk and indicates any changes taking place in the concentration of acidic compounds in the milk, even if the $\mathrm{pH}$ remains unchanged [61]. In the present study, the active acidity ( $\mathrm{pH}$ value) and potential acidity (titrimetric, in ${ }^{\circ} \mathrm{SH}$ ) were found to meet the requirements of Polish standard PN-A-86003/A1:1998 [62] for drinking milk, according to which the $\mathrm{pH}$ value of heat-treated milk should be 6.6-6.8 and titrimetric acidity should be $6.0-7.5^{\circ} \mathrm{SH}$. The content of basic ingredients (dry matter, fat, protein, and lactose) was typical for processing milk, consistent with the results of other authors [63].

\subsection{Yoghurts}

\subsubsection{Acidity}

The acidity of the experimental yoghurts was within the normal range [33], according to which titrimetric acidity expressed as lactic acid content should be at least $0.6 \%$. Comparable results were obtained by Selvamuthukumaran and Farhath [28], who found a higher level of lactic acid in sea buckthorn fruit syrup yoghurt (15\% added to milk) when compared with plain yoghurt. The initial lactic acid content was $0.86 \%$, and rose to $1.15 \%$ at 21 days, when stored at $4{ }^{\circ} \mathrm{C}$. Kudełka [64] observed that, during 21-day storage of natural yoghurt in refrigerated conditions, the amount of lactic acid generated steadily increased. It should be emphasized that the increase in acidity of fruit yoghurt is a normal phenomenon. According to Selvamuthukumaran and Farhath [28], the addition of sea buckthorn pulp positively influences the enrichment of lactic acid content from yoghurt with probiotic culture. Increases in lactic acid content may be due to a small extent of sea buckthorn pulp due to the addition of organic acids. Moreover, the decrease in the $\mathrm{pH}$ value during the 
storage was indicated by Gunenc et al. [25], who investigated sea buckthorn whole fruit and sea buckthorn purified mucilage as additives into yoghurt (28-day storage at $4{ }^{\circ} \mathrm{C}$ ).

\subsubsection{Nutritional Value}

The obtained results are partially consistent (only in terms of the direction of the changes) with the results of other authors [28]. Generally, there is one publication in the literature devoted to the nutritional value of yoghurts with the addition of sea buckthorn in the form of fruit syrup. Selvamuthukumaran and Farhath [28] obtained a higher content of total solids, fat, and protein in relation to our results. Their result shows that the total solids of fruit yoghurt decreased from $28.9 \%$ to $28.4 \%$ during 21 -day storage at $4{ }^{\circ} \mathrm{C}$, protein from $7.90 \%$ to $7.34 \%$, and fat from $5.40 \%$ to $5.15 \%$, respectively. Therefore, the direction and magnitude of the changes were comparable. The obtained significant decrease $(p \leq 0.05)$ in dry matter content could be due to syneresis, i.e., leakage of whey, which contains whey proteins, lactose, and minerals. Lee and Lucey [65] indicated that dry matter content and the ratio of casein to whey proteins are important factors influencing the water-holding capacity of yoghurt curd. Other of ours studies showed a decrease in the dry matter content in natural yoghurts during storage [66].

\subsubsection{Sensory Evaluation}

Sensory evaluation, taking into account colour, consistency, flavor, and aroma, is a key tool enabling the assessment of consumer acceptance of a new product. The factors playing the most important role in determining the market behaviour of consumers, including in the case of yoghurt, include freshness, flavor, and aroma. These characteristics directly depend on the acidity, including the lactic acid content, free fatty acids, and volatile compounds content $[67,68]$. In our research, the decrease in acidity was not very high in the initial day and during storage; therefore, the general acceptance of yoghurts was satisfactory (above 4.54 points / 5 max points for the yoghurts with the addition). As reported by Selvamuthukumaran and Farhath [28], the fresh sea buckthorn fruit yoghurt had an overall acceptability score of 8.0 (on nine-point hedonic scale). A score of 6.1 was taken as the lowest limit, implying the end-of-shelf-life of yoghurts. Sensory acceptance of fruit yoghurts remained up to 18 days during storage at $4{ }^{\circ} \mathrm{C}$. Moreover, Dabija et al. [29], optimizing the fruit yoghurt production, stated that yoghurt with the best physico-chemical and sensory properties was obtained by adding $1.75 \%$ sea buckthorn powder combined with $0.25 \%$ grape seed extract (4.22 points for the taste, 4.14 for the mouth feel, 4.58 for the texture, and 4.27 for the overall acceptability). However, research by Grega et al. [69] showed that the type of bacterial culture used also determines the sensory quality during storage. ABT-1 is generally a very well-accepted yoghurt culture, with mild aroma and flavour.

\subsubsection{Microbiological Evaluation}

The activity of the appropriate groups of microorganisms is the basic indicator of the microbiological quality of yoghurt. Apart from the presence of typical flora, its survival is important during the entire shelf-life of the product [70]. The conducted microbiological analysis showed that the dominant species of the characteristic microflora of the tested yoghurts were lactic acid bacteria and bacteria of the genus Lactobacillus and Bifidobacterium derived from the starter culture. An appropriately high concentration of these microorganisms allows to obtain a product with the expected flavour and aroma. According to the guidelines of the Codex Alimentarius [71], the number in one gram of product should be at least $10^{7} \mathrm{cfu}$ [72]. In the current study, this value was obtained and maintained throughout the storage period of material batches. Maintaining high concentrations of yoghurt bacteria in refrigerated storage is difficult. Many studies have shown that the number of yoghurt bacteria is then reduced to a level lower than $10^{7} \mathrm{cfu} / \mathrm{g}$ [73]. According to Augustyniak's research [74], only a few percent of yoghurts had the desired number of live lactobacilli during the final storage period. The addition of fruit filling, as research 
showed, could reduce the number of yoghurt bacteria [75]. In the present study, such an effect of sea buckthorn mousse on lactic acid bacteria, Lactobacillus, was not observed, and a temporary decrease in the concentration of Bifidobacterium was recorded only in the first week of storage. A high concentration of yoghurt bacteria determines their functional and probiotic features. Research has shown that the application of lactic acid microorganisms in the diet has a positive effect on the stimulation of the body's immune processes by increasing lymphocyte activity, stabilizing intestinal microbiota, and improving nutrient digestibility and assimilation [76]. Hygienic quality is an important aspect of the shelf life and quality of yoghurt during storage. No growth of saprophytic and pathogenic flora of fecal origin, anaerobic microorganisms, or pathogenic Salmonella and Campylobacter bacilli was observed in the conducted experiments. This confirms the effectiveness of the pasteurization process and good quality of the raw material. These results were consistent with those obtained by other authors, who indicated a small percentage of the tested batches of marketed yoghurts [75,77]. The presence of yeast-like fungi at the level of $10^{2}$, noted in yoghurt enriched with sea buckthorn mousse, and their persistence throughout the storage period, should be attributed to the contamination of the additive. Their presence could indicate that the yoghurt batch was deteriorating quickly [78]. The lack of fungal flora development in the tested yoghurt batch was the result of the antagonistic effect of lactic acid against yeast cells. At the same time, an increase in the number of yeasts could stimulate the development of lactic acid bacteria and lower $\mathrm{pH}$ of the product, while protecting it against the development of unfavourable flora. This synergism has not been fully elucidated and requires further research on the flora of fermented milk products [79]. This is a result indicating that, despite the high quality of the raw material and the application of thermal disinfection treatments of milk batches, additives of natural origin can be a source of contamination of the final product. Simultaneously, the presence of yeast does not always have to be a negative phenomenon, and with appropriate cooling conditions, preventing their uncontrolled growth, it can stimulate a favourable yoghurt flora.

\subsubsection{Microstructure Analysis}

The higher number of bonds reported in our research probably contributed to the increase in yoghurt cohesiveness and elasticity. The recorded microstructure of cow's milk yoghurt was characteristic, similar to that recorded by Akalın [80]. For this reason, yoghurt without the addition of sea buckthorn was characterized by higher hardness and cohesiveness. The yoghurt microstructure obtained by adding sea buckthorn is more desirable from a health and nutritional point of view. More empty spaces as well as thinner chains will contribute to a higher digestibility of the product because of the larger surface area available for acid action and gastrointestinal enzymes, as well as potentially faster degradation of the thus formed gel network. The loss of the initial structure by yoghurt with the addition of sea buckthorn after 21 days of refrigerated storage compared with yoghurt on day " 0 " and yoghurt without the addition of sea buckthorn is the result of the degradation changes taking place.

\subsubsection{FTIR Measurements}

All panels in Figure 5 showed that the samples selected for testing had a fairly clear infrared spectrum, which was consistent with the literature data, and additionally proved the good quality of the samples selected for testing. Regardless of the yoghurt type, it should be noted that the positions of the bands related to protein structures and fat content assumed the same location, which was an additional argument for the above thesis.

Firstly, Panel A, which shows spectra from the initial phase of the experiment, is very interesting. As can be observed, the spectra of plain, natural yoghurt (black line) and yoghurt with sea buckthorn mousse (red line) differ significantly in some areas. A band with a maximum at $1744 \mathrm{~cm}^{-1}$ had a much greater intensity in the sample of yoghurt with mousse. This confirmed the higher protein content of this sample, as shown by previous results obtained using other methods. In addition, the higher intensity of the bands from 
the $1000-1700 \mathrm{~cm}^{-1}$ region for yoghurt with the addition of sea buckthorn indicated a much higher content of polysaccharide additives. In addition, there was also a clearly greater intensity of bands corresponding to the vibrations from the $2970-2840 \mathrm{~cm}^{-1}$ area related to fat content. A greater intensity of vibrations in the range from 1460 to $1230 \mathrm{~cm}^{-1}$ and greater band intensity in this range was also visible in the entire region. However, it was the part of the region that consisted of vibrations from fatty acids, proteins, and polysaccharides. However, it was more a consequence/connection of the aforementioned regions and confirmed the above discussion.

The second research aspect in this paper was the observation of sample stability and aging effects occurring in them. For this purpose, the samples were measured at weekly intervals. During the experiment, degradation changes occurred in the structure of amino acids and fats present in the tested yoghurts.

Preliminary analysis of FTIR spectra showed that the applied additives did not have a detrimental effect on the position of the main bands in the spectra, thus they did not change the internal structure of the samples in any way. A very interesting effect could be observed in the next panels in Figure 5, where the measurements of the spectra from the following measurement days are presented. As can be seen, the greatest changes in samples for individual components occurred in the initial phase of the experiment. However, along with the duration of the experiment, changes between individual bands practically completely disappeared in the fourth week. This very interesting result demonstrated that, regardless of the addition to the yoghurt, individual components degrade over time in the same or similar manner. This meant that the additive from the molecular aspect did not significantly affect the shelf life of the product. It should also be noted that, during the experiment, it is clearly visible that the content of the protein and fat fractions is decreasing, which is also reflected in other studies.

\section{Conclusions}

In Poland, the application of new, plant-based additives in dairy production is still at the stage of development. Gradually, consumers are moving away from their usual habits and increasingly turning to new dairy products. The present study showed the possibility of using sea buckthorn fruit mousse in the production of fermented milk beverages, specifically yoghurts. Fruit filling is an added value to the product as it is a valuable source of nutrients in itself. The produced yoghurts were characterized by an adequate acidity and high nutritional value. Yoghurt with sea buckthorn addition was generally characterized by a higher active acidity and lactic acid content throughout the entire study period (21 days of storage). It was also fully sensory accepted by the evaluation panel. The conducted microbiological tests confirmed the high sanitary and hygienic quality of the analysed yoghurts at all test time points. No growth of fecal coliform bacteria, Escherichia coli, spores of anaerobic flora of the species Clostridium perfringens as well as Salmonella and Campylobacter species was recorded in any yoghurts during refrigerated storage. The obtained results indicated that the obtained chemical composition was related to the structural image. Moreover, the applied yoghurt additive was visible at the spectral level (FTIR infrared spectra) as an increase in the intensity of the characteristic bands for vibrations related to protein, fat, and polysaccharide structures. The greatest changes were observed for vibrations ranging from 2960 to 2840 , from 1160 to $1000 \mathrm{~cm}^{-1}$, and in the band with the maximum at about $1744 \mathrm{~cm}^{-1}$. However, these changes require further and more detailed research, which will be carried out in subsequent research stages.

Author Contributions: Conceptualization, A.B. and P.G.; data curation, A.B., J.K., A.M., T.C., and Ł.W.; formal analysis, A.B., A.M., T.C., and Ł.W.; investigation, A.B., J.K., A.M., T.C., and Ł.W.; methodology, A.B., J.K., A.M., T.C., P.G., and Ł.W.; project administration, A.B.; resources, A.B., J.K., A.M., T.C., P.G., Ł.W., and A.L.; visualization, A.B., A.M., T.C., and Ł.W.; writing-original draft preparation, A.B., J.K., A.M., T.C., P.G., Ł.W., and A.L.; writing-review and editing, A.B., A.M., T.C., and $€$.W. All authors have read and agreed to the published version of the manuscript. 
Funding: This research was funded by the Ministry of Science and Higher Education as part of the "Regional Initiative of Excellence" program for 2019-2022, project number 029/RID/2018/19.

Institutional Review Board Statement: Not applicable.

Informed Consent Statement: Not applicable.

Data Availability Statement: Not applicable.

Conflicts of Interest: The authors declare no conflict of interest.

\section{References}

1. Aryana, K.J.; Olson, D.W. A 100-Year Review: Yogurt and other cultured dairy products. J. Dairy Sci. 2017, 100, 9987-10013. [CrossRef] [PubMed]

2. Granato, D.; Santos, J.S.; Salem, R.D.S.; Mortazavian, A.M.; Rocha, R.S.; Cruz, A.G. Effects of herbal extracts on quality traits of yogurts, cheeses, fermented milks, and ice creams: A technological perspective. Curr. Opin. Food Sci. 2018, 19, 1-7. [CrossRef]

3. Sarfraz, F.; Farooq, U.; Shafi, A.; Hayat, Z.; Akram, K.; Rehman, H.U. Hypolipidaemic effects of synbiotic yoghurt in rabbits. Int. J. Dairy Technol. 2019, 72, 545-550. [CrossRef]

4. El-Shafei, S.M.S.; Sakr, S.S.; Abou-Soliman, N.H.I. The impact of supplementing goats' milk with quinoa extract on some properties of yoghurt. Int. J. Dairy Technol. 2020, 73, 126-133. [CrossRef]

5. Lucatto, L.N.; da Silva-Buzanello, R.A.; de Mendonça, S.N.T.G.; Lazarotto, T.C.; Sanchez, J.L.; Bona, E.; Drunkler, D.A. Performance of different microbial cultures in potentially probiotic and prebiotic yoghurts from cow and goat milks. Int. J. Dairy Technol. 2020 73, 144-156. [CrossRef]

6. FAO/WHO. Codex Alimentarius: Milk and Milk Products. Codex Standard for Fermented Milk; 2011; pp. 6-16. Available online: http:/ / www.fao.org/3/i2085e/i2085e00.pdf (accessed on 27 October 2020).

7. Routray, W.; Mishra, H.N. Scientific and technical aspects of yoghurt aroma and taste: A review. Compr. Rev. Food Sci. Food Saf. 2011, 10, 208-220. [CrossRef]

8. Barros, C.P.; Guimarães, J.T.; Esmerino, E.A.; Duarte, M.C.K.; Silva, M.C.; Silva, R.; Ferreira, B.M.; Sant'Ana, A.S.; Freitas, M.Q.; Cruz, A.G. Paraprobiotics, postbiotics and psychobiotics: Concepts and potential applications in dairy products. Curr. Opin. Food Sci. 2020, 32, 1-8. [CrossRef]

9. Roobab, U.; Batool, Z.; Manzoor, M.F.; Shabbir, M.A.; Khan, M.R.; Aadil, R.M. Sources, formulations, advanced delivery and health benefits of probiotics. Curr. Opin. Food Sci. 2020, 32, 17-28. [CrossRef]

10. Champagne, C.P.; Gomes da Cruz, A.; Daga, M. Strategies to improve the functionality of probiotics in supplements and foods. Curr. Opin. Food Sci. 2018, 22, 160-166. [CrossRef]

11. Hill, C.; Guarner, F.; Reid, G.; Gibson, G.R.; Merenstein, D.J.; Pot, B.; Morelli, L.; Canani, R.B.; Flint, H.J.; Salminen, S.; et al. The International Scientific Association for Probiotics and Prebiotics consensus statement on the scope and appropriate use of the term probiotic. Nat. Rev. Gastroenterol. Hepatol. 2014, 11, 506-514. [CrossRef]

12. Herrero-Barbudo, M.C.; Granado-Lorencio, F.; Blanco-Navarro, I.; Olmedilla-Alonso, B. Retinol, $\alpha$ - and $\gamma$-tocopherol and carotenoids in natural and vitamin A- and E-fortified dairy products commercialized in Spain. Int. Dairy J. 2005, 15, 521-526. [CrossRef]

13. Brodziak, A.; Król, J.; Litwińczuk, Z.; Florek, M. Bioactive compound levels and sensory quality of partially skimmed organic yoghurts: Effects of the milk treatment, production season and starter culture. Int. J. Dairy Technol. 2020. [CrossRef]

14. Mojka, K. Characteristics of fermented milk drinks. Probl. Hig. Epidemiol. 2013, 94, 722-729.

15. Glibowski, P.; Rybak, P. Rheological and sensory properties of stirred yoghurt with inulin-type fructans. Int. J. Dairy Technol. 2016, 69, 122-128. [CrossRef]

16. Kushkevych, I.; Kotrsová, V.; Dordević, D.; Buňková, L.; Vítězová, M.; Amedei, A. Hydrogen sulfide effects on the survival of Lactobacilli with emphasis on the development of inflammatory bowel diseases. Biomolecules 2019, 9, 752. [CrossRef]

17. Savaiano, D.A. Lactose digestion from yogurt: Mechanism and relevance. Am. J. Clin. Nutr. 2014, 99, 1251S-1255S. [CrossRef] [PubMed]

18. Liu, D. Effect of Fuzhuan brick-tea addition on the quality and antioxidant activity of skimmed set-type yoghurt. Int. J. Dairy Technol. 2018, 71, 22-33. [CrossRef]

19. Mercan, E.; Sert, D.; Karakavuk, E.; Akin, N. Effect of different levels of grapeseed (Vitis vinifera) oil addition on physicochemical, microbiological and sensory properties of set-type yoghurt. Int. J. Dairy Technol. 2018, 71, 34-43. [CrossRef]

20. Yildiz, E.; Ozcan, T. Functional and textural properties of vegetable-fibre enriched yoghurt. Int. J. Dairy Technol. 2019, 72, 199-207. [CrossRef]

21. Gut, M.; Gasik, A.; Mitek, M. Sea buckthorn-A plant like a pharmacy. Przem. Spoż. 2008, 6, 36-38.

22. Ting, H.C.; Hsu, Y.W.; Tsai, C.F.; Lu, F.J.; Chou, M.C.; Chen, W.K. The in vitro and in vivo antioxidant properties of seabuckthorn (Hippophaë rhamnoides L.) seed oil. Food Chem. 2011, 125, 652-659. [CrossRef]

23. Banach, K.; Rutkowska, B.; Glibowski, P. Polska "super żywność" w prewencji chorób nowotworowych. Bromat. Chem. Toksykol. 2017, 2, 106-114. 
24. Mateuszuk, K.; Biel, W. Sea buckthorn (Hippophae rhamnoides L.) is a valuable source of food additives. Przem. Spoż. 2020, 74, 33-36.

25. Gunenc, A.; Khoury, C.; Legault, C.; Mirrashed, H.; Rijke, J.; Hosseinian, F. Seabuckthorn as a novel prebiotic source improves probiotic viability in yogurt. LWT Food Sci. Technol. 2016, 66, 490-495. [CrossRef]

26. Terpou, A.; Gialleli, A.J.; Bosnea, L.; Kanellaki, M.; Koutinas, A.A.; Castro, G.R. Novel cheese production by incorporation of sea buckthorn berries (Hippophae rhamnoides L.) supported probiotic cells. LWT Food Sci. Technol. 2017, 79, 616-624. [CrossRef]

27. Tifrea, A.; Tiţa, O.; Máthé, E.; Ketney, O. Physicochemical parameters of probiotic yoghurt with bioactive natural products from sea buckthorn. Acta Univ. Cibinien. Ser. E Food Technol. 2013, 17, 27-38. [CrossRef]

28. Selvamuthukumaran, M.; Farhath, K. Evaluation of shelf stability of antioxidant rich seabuckthorn fruit yoghurt. Int. Food Res. J. 2014, 21, 759-765.

29. Dabija, A.; Oroian, M.A.; Mironeasa, S.; Sidor, A.M. Physicochemical and sensory properties of yogurt with seabuckthorn powder, rosehip powder and grape seed extract during storage. In Proceedings of the 18th International Multidisciplinary Scientific GeoConference SGEM 2018, Albena, Bulgaria, 2-8 July 2018; pp. 1-9.

30. PN-68/A-86122. Milk. Research Methods. Available online: https://sklep.pkn.pl/ (accessed on 14 September 2020).

31. AOAC-Official Methods of Analysis, No. 998.06, 17th ed.; AOAC International: Arlington, VA, USA, 2000; Available online: http:/ / m.wdfxw.net/goDownFiles.aspx?key=12212363 (accessed on 15 September 2020).

32. PN-EN ISO 4833-2:2013. Microbiology of the Food Chain-Horizontal Method for the Enumeration of Microorganisms-Part 2: Colony Count at 30 Degrees C by the Surface Plating Technique. Available online: https://sklep.pkn.pl/ (accessed on 15 September 2020).

33. PN-A-86061:2002. Milk and Milk Products. Fermented Milk. Available online: https://sklep.pkn.pl/ (accessed on 4 September 2020).

34. PN-EN ISO 8968-1:2014. Milk and milk Products-Determination of Nitrogen Content-Part 1: Kjeldahl Principle and Crude Protein Calculation. Available online: https:/ / sklep.pkn.pl (accessed on 15 September 2020).

35. Baryłko-Pikielna, N.; Matuszewska, I. Sensory food testing. In Basics. Methods. Usage, 2nd ed.; PTTŻ Scientific Publisher: Krakov, Poland, 2014; pp. 267-275.

36. PN-EN ISO 7218:2008/A1:2013-10. Food and Feed Microbiology-General Requirements and Principles of Microbiological Testing. Available online: https:/ / sklep.pkn.pl/ (accessed on 15 September 2020).

37. PN-EN ISO 6887-5:2020-10. Food Chain Microbiology_Preparation of Samples, Stock Suspension and Tenfold Dilutions for Microbiological Analysis-Part 5: Specific Guidelines for the Preparation of Milk and Milk Products. Available online: https: / / sklep.pkn.pl/ (accessed on 15 September 2020).

38. PN-ISO 7889:2007. Yogurt-Enumeration of Characteristic Microorganisms-Colony Count Technique at $37^{\circ} \mathrm{C}$. Available online: https: / / sklep.pkn.pl/ (accessed on 15 September 2020).

39. PN-ISO 6611: 2007. Milk and milk Products—Enumeration of Colony Forming Units of Yeast and/or Mold—Plate Method at $25^{\circ} \mathrm{C}$. Available online: https://sklep.pkn.pl/ (accessed on 15 September 2020).

40. PN-ISO 4832:2007. Food and Feed Microbiology-Horizontal Method for the Enumeration of Coliform Bacteria-Plate Method. Available online: https:/ / sklep.pkn.pl/ (accessed on 15 September 2020).

41. PN-ISO 15213:2005. Food and Feed Microbiology-Horizontal Method for the Enumeration of Sulphate (IV) Reducing Bacteria Growing under Anaerobic Conditions. Available online: https://sklep.pkn.pl/ (accessed on 15 September 2020).

42. PN-ISO 20128:2012. Dairy Products—Enumeration of Putative Lactobacillus acidophilus on a Selective Medium-Colony Count Technique at $37^{\circ} \mathrm{C}$. Available online: https:/ / sklep.pkn.pl/ (accessed on 15 September 2020).

43. ISO 29981:2010. Milk Products-Enumeration of Presumptive Bifidobacteria—Colony Count Technique at $37^{\circ} \mathrm{C}$. Available online: https: / / sklep.pkn.pl/ (accessed on 15 September 2020).

44. PN-EN ISO 6579-1:2017-04. Food Chain Microbiology-Horizontal Detection Method, Enumeration and Serotyping of SalmonellaPart 1: Salmonella spp. Detection. Available online: https:/ /sklep.pkn.pl/ (accessed on 15 September 2020).

45. Ahmed, Z.; Wang, Y.; Anjum, N.; Ahmad, H.; Ahmad, A.; Raza, M. Characterization of new exopolysaccharides produced by coculturing of L. kefiranofaciens with yoghurt strains. Int. J. Biol. Macromol. 2013, 59, 377-383. [CrossRef]

46. Chen, Z.; Shi, J.; Yang, X.; Nan, B.; Liu, Y.; Wang, Z. Chemical and physical characteristics and antioxidant activities of the exopolysaccharide produced by Tibetan kefir grains during milk fermentation. Int. Dairy J. 2015, 43, 15-21. [CrossRef]

47. Adam, M.; Dobiáš, P. Comparison of various methods for determination of water in white yoghurts. Food Chem. 2009, 115, 1069-1073. [CrossRef]

48. Bater, C.; Galmarini, M.S. Influence of different storage conditions on the performance of spray-dried yogurt used as inoculum for milk fermentation. J. Dairy Sci. 2019, 86, 354-360. [CrossRef] [PubMed]

49. Darwish, A.M.; Khalifa, R.E. Functional properties of chia seed mucilage supplemented in low fat yoghurt. Alex. Sci. Exch. J. 2018, 39, 450-459. [CrossRef]

50. El-Kholy, W.M.; Soliman, T.N. Evaluation of date palm pollen (Phoenix dactylifera L.) encapsulation, impact on the nutritional and functional properties of fortified yoghurt. PLoS ONE 2019, 14, e222789. [CrossRef] [PubMed]

51. Jaafar, A.A.; Atyea, A.S. Study and evaluation of yoghurt products prepared from various commercial starter cultures. Plant Arch. 2020, 20, 3250-3254.

52. Jaya, S. Microstructure analysis of dried yogurt: Effect of different drying methods. Int. J. Food Prop. 2009, 12, 469-481. [CrossRef] 
53. Khanmohammadi, M.; Garmaudi, A.B. Artificial neural network for quantitative determination of total protein in yogurt by infrared spectrometry. Microchem. J. 2009, 91, 47-52. [CrossRef]

54. Moros, J.; Iñón, F.A. Evaluation of the application of attenuated total reflectance-Fourier transform infrared spectrometry (ATR-FTIR) and chemometrics to the determination of nutritional parameters of yogurt samples. Anal. Bioanal. Chem. 2006, 385, 708-715. [CrossRef]

55. Mudgil, P.; Jumah, B. Rheological, micro-structural and sensorial properties of camel milk yogurt as influenced by gelatin. LWT Food Sci. Technol. 2018, 98, 646-653. [CrossRef]

56. Nazari, M.; Nazari, M. Garlic essential oil nanophytosomes as a natural food preservative: Its application in yogurt as food model. Colloids Interface Sci. 2019, 30, 100176. [CrossRef]

57. Temizkan, R.; Can, A.; Dogan, M.A.; Mortas, M.; Ayvaz, H. Rapid detection of milk fat adulteration in yoghurts using near and mid-infrared spectroscopy. Int. Dairy J. 2020, 110, 104795. [CrossRef]

58. Yuan, H.; Lv, J. Secondary structures and their effects on antioxidant capacity of antioxidant peptides in yogurt. Int. J. Food Prop. 2018, 21, 2167-2180. [CrossRef]

59. da Silva, S.C.; Fenandes, I.P. Spray-dried Spirulina platensis as an effective ingredient to improve yogurt formulations: Testing different encapsulating solutions. J. Funct. Foods 2019, 60, 103427. [CrossRef]

60. Codex Alimentarius International Food Standards, Code of Hygienic Practice for Milk and Milk Products, No. CAC/RCP 57-2004, Modified in 2009. 2009. Available online: http:/ / www.fao.org/fao-who-codexalimentarius/sh-proxy/en/?lnk=1\&url=https\% 253A\%252F\%252Fworkspace.fao.org\%252Fsites\%252Fcodex\%252FStandards\%252FCXC\%2B57-2004\%252FCXC_057e.pdf (accessed on 4 September 2020).

61. Lorenzen, P.C.; Clawin-Rädecker, I.; Einhoff, K.; Hammer, P.; Hartmann, R.; Hoffmann, W.; Martin, D.; Molkentin, J.; Walte, H.G.; Devrese, A. A survey of the quality of extended shelf life (ESL) milk in relation to HTST and UHT milk. Int. J. Dairy Technol. 2011, 64, 166-178. [CrossRef]

62. PN-A-86003/A1:1998. Milk and Dairy Products-Drinking Milk. Available online: https:/ /sklep.pkn.pl (accessed on 17 September 2020).

63. Brodziak, A.; Król, J.; Litwińczuk, Z.; Nowakowicz-Dębek, B.; Czernecki, T. Effect of cold chain retention on the nutritional value of drinking milk, including content of bioactive components. Przem. Chem. 2017, 96, 1378-1380. (In Polish)

64. Kudełka, W. The Possibility of Modelling the Quality of Fermented Milk Beverages during Storage; Economics University in Cracow Publishing: Cracow, Poland, 2008. (In Polish)

65. Lee, W.J.; Lucey, J.A. Formation and physical properties of yoghurt. Asian Aust. J. Anim. Sci. 2010, 23, 1127-1136. [CrossRef]

66. Brodziak, A.; Król, J.; Barłowska, J.; Teter, A.; Florek, M. Changes in the physicochemical parameters of yoghurts with added whey protein in relation to the starter bacteria strains and storage time. Animals 2020, 10, 1350. [CrossRef] [PubMed]

67. Chen, C.; Zhao, S.; Hao, G.; Yu, H.; Tian, H.; Zhao, G. Role of lactic acid bacteria on the yogurt flavour: A review. Int. J. Food Prop. 2017, 20, S316-S330. [CrossRef]

68. Cheng, H. Volatile flavor compounds in yogurt: A review. Crit. Rev. Food Sci. Nutr. 2010, 50, 938-950. [CrossRef]

69. Grega, T.; Sady, M.; Wszołek, M.; Gambuś, H. Evaluation of the quality of yoghurts with the addition of amaranth seeds. Przegl. Mlecz. 2001, 5, 223-226. (In Polish)

70. Kycia, K.; Krysiński, C. Microbiological and hygienic quality of commercial goat milk yoghurts in context of their therapeutic properties. Probl. Hig. Epidemiol. 2014, 95, 186-191.

71. Codex Stan 243-2003. Codex Standard for Fermented Milks 2003. Available online: http://www.fao.org/fao-whocodexalimentarius / sh-proxy / en / ?lnk=1\&url=https $\% 253 \mathrm{~A} \% 252 \mathrm{~F} \% 252 \mathrm{Fw}$ orkspace.fao.org $\% 252 \mathrm{Fsites} \% 252 \mathrm{Fcodex} \% 25$ 2FStandards\%252FCXS\%2B243-2003\%252FCXS_243e.pdf (accessed on 30 November 2020).

72. Birollo, G.A.; Reinheimer, J.A. Viability of lactic acid microflora in different types of yoghurt. Food Res. Int. 2000, 33, 799-805. [CrossRef]

73. Tamime, A.Y.; Robinson, R.K. Yoghurt: Science and Technology, 1st ed.; Woodhead: Cambridge, UK, 2007.

74. Augustyniak, A. Survival of Lactic Acid Bacteria in Yoghurts during Cold Storage. Master's Thesis, SGGW, Warsaw, Poland, 2012.

75. Ranadheera, C.S.; Evans, C.A. Probiotic viability and physico-chemical and sensory properties of plain and stirred fruit yogurts made from goat's milk. Food Chem. 2012, 135, 1411-1418. [CrossRef] [PubMed]

76. Zmarlicki, S. Health aspects of milk and milk products. Zdr. Publ. 2006, 116, 142-146.

77. Molska, I. The importance of Enterobacteriaceae bacteria in food products. Przem. Spoż. 2007, 61, 30-32.

78. Fleet, G.H. Yeasts in dairy products. A review. J. Appl. Bacteriol. 1990, 68, 199-211. [CrossRef]

79. Viljoena, B.C.; Lourens-Hattingh, A.; Ikalafenga, B.; Peter, G. Temperature abuse initiating yeast growth in yoghurt. Food Res. Int. 2003, 36, 193-197. [CrossRef]

80. Akalın, A.S.; Unal, G.; Dinkci, N.; Hayaloglu, A.A. Microstructural, textural, and sensory characteristics of probiotic yogurts fortified with sodium calcium caseinate or whey protein concentrate. J. Dairy Sci. 2012, 95, 3617-3628. [CrossRef] [PubMed] 